\title{
Role of IL-10 polymorphisms in susceptibility to hepatitis B virus-related hepatocellular carcinoma
}

\author{
M.W. Peng', S.Q. Lu², J. Liu' ${ }^{1}$ and C.Y. Dong ${ }^{1}$ \\ ${ }^{1}$ Laboratory of Molecular Virus \& Cancer, State Key Laboratory of Virology, \\ Wuhan University School of Basic Medicine, Wuhan University, Wuhan, China \\ ${ }^{2}$ Department of Anesthesiology, Hubei Cancer Hospital, Hongshan, Wuhan, China

ABSTRACT. We conducted a case-control study to investigate the role of three common single nucleotide polymorphisms of IL-10 (-592G/A, -819T/ $\mathrm{C}$, and $-1082 \mathrm{~A} / \mathrm{C}$ ) in the development of hepatitis B virus (HBV)-related hepatocellular carcinoma (HCC). The study included $173 \mathrm{HBV}$-related HCC patients and 182 healthy controls. A polymerase chain reaction-restriction fragment length polymorphism assay was applied to assess the sequence variants of interest. Compared with control subjects, HCC patients were more likely to be older $(t=1.94, \mathrm{P}=0.03)$, have a family history of cancer (chi square $=17.86, P<0.001)$, and exhibit higher alanine transaminase $(t=$ 13.32, $P<0.001)$ and aspartate transaminase $(t=12.63, P<0.001)$ levels. Using unconditional logistic regression analyses, we found that the GG genotype of $-592 \mathrm{G} / \mathrm{A}$ was associated with increased risk of $\mathrm{HCC}$ [odds ratio $(\mathrm{OR})=2.20,95 \%$ confidence interval $(\mathrm{Cl})=1.12-4.38]$, compared to the AA genotype. Under a dominant model, the AG+GG genotype correlated with HBV-related HCC susceptibility compared to the AA genotype, with an OR $(95 \% \mathrm{Cl})$ of $1.56(1.02-2.48)$. Moreover, a recessive model showed the GG genotype to be associated with elevated risk of HCC compared to the 


\begin{abstract}
$A A+A G$ genotype $(O R=1.85,95 \% \mathrm{Cl}=1.01-3.47)$. However, no significant association between the $-819 \mathrm{~T} / \mathrm{C}$ and $-1082 \mathrm{~A} / \mathrm{C}$ variants and development of HBV-related HCC was observed under codominant, dominant, and recessive models. We conclude that the $I L-10-592 \mathrm{G} / \mathrm{A}$ polymorphism does play a role in susceptibility to HBV-related HCC under codominant, dominant, and recessive models.
\end{abstract}

Key words: IL-10; Polymorphism; Hepatitis B virus; Hepatocellular carcinoma

\title{
INTRODUCTION
}

Hepatocellular carcinoma ( $\mathrm{HCC}$ ) counts among the most important health problems worldwide, especially in developing countries (Ferlay et al., 2013). The etiology of HCC is poorly understood, and its development involves many complex environmental and lifestyle aspects (Ma et al., 2014). Hepatitis B virus (HBV) is reported to be an important influence in the development of HCC (Yang et al., 2008). However, the morbidity of HCC varies substantially between similarly HBV exposed subjects, suggesting that genetic factors may contribute to its development. Indeed, previous studies have indicated that many genetic aspects can affect HCC susceptibility (Zhao et al., 2014; Labib et al., 2015; Liu et al., 2015; Sheu et al., 2015; Zhang et al., 2015a; Zhao et al., 2015; Zheng et al., 2015).

Interleukin-10 (IL-10) is a pleiotropic cytokine, and a wealth of evidence supports its regulatory role in carcinogenesis and tumor growth (Tanikawa et al., 2012; Holan et al., 2014). Observational studies have reported high serum levels of IL-10 in patients with a variety of solid tumors, including HCC (Rad et al., 2004; Szkaradkiewicz et al., 2010; Kim et al., 2012). It is therefore reasonable to consider the $I L-10$ gene a candidate factor in cancer susceptibility. Previous studies have examined associations between IL-10 polymorphisms and HCC risk, but with inconclusive results (Tseng et al., 2006; Wang et al., 2006; Truelove et al., 2008; Wei et al., 2011; Yu et al., 2013). Therefore, we conducted a case-control study to investigate the role of three common IL-10 single nucleotide polymorphisms (SNPs; -592G/A, -819T/C, and -1082A/C) in the development of HBV-related HCC.

\section{MATERIAL AND METHODS}

\section{Subjects}

A case-control design was used in our study, which included $173 \mathrm{HBV}$-related HCC patients and 182 healthy controls. HCC patients were recruited between December 2012 and September 2014, and diagnoses were confirmed by pathologic findings. All HCC patients were verified as HBV-positive using cytological tests. Control subjects were diagnosed as being free of $\mathrm{HBV}$, any malignant tumors, and other serious liver and kidney diseases.

Demographic and lifestyle data were collected from all HCC patients and control subjects with a self-designed questionnaire. These included gender, age, tobacco and alcohol consumption, and family history of cancer. Clinical information, comprising alanine aminotransferase (ALT) and aspartate aminotransferase (AST) levels, tumor-node-metastasis (TNM) stage, and Child-Pugh classification were collected from medical records with patients' consent. A signed informed 
consent form was obtained from all participants before their inclusion in the study. Furthermore, the Ethical Committee of the Wuhan University School of Basic Medicine approved the study protocols.

\section{DNA extraction and SNP genotyping}

A peripheral blood sample $(5 \mathrm{~mL})$ was obtained from each patient and control subject, and kept at $-20^{\circ} \mathrm{C}$ until needed. DNA was extracted from these samples using the TIANamp Blood DNA Kit (TIANGEN Biotech, Beijing, China). A polymerase chain reaction (PCR)restriction fragment length polymorphism assay was applied to assess IL-10 -592G/A, -819T/ $\mathrm{C}$, and $-1082 \mathrm{~A} / \mathrm{C}$ sequence variations. The PCR was performed with an initial denaturation at $94^{\circ} \mathrm{C}$ for $5 \mathrm{~min}$, followed by 35 cycles of denaturation at $94^{\circ} \mathrm{C}$ for $30 \mathrm{~s}$, annealing at $56^{\circ} \mathrm{C}$ for $45 \mathrm{~s}$, and extension at $72^{\circ} \mathrm{C}$ for $60 \mathrm{~s}$, before a final extension step at $72^{\circ} \mathrm{C}$ for $10 \mathrm{~min}$. PCR products were visualized after electrophoresis on a $3 \%$ agarose gel stained with $0.1 \%$ ethidium bromide.

\section{Statistical analysis}

All statistical analyses were conducted using SPSS for Windows, Version 16.0 (SPSS Inc., Chicago, IL, USA). Hardy-Weinberg equilibrium (HWE) was tested by goodness-of-fit chisquare tests for each SNP in the patient and control groups. Unconditional logistic regression analysis was employed to analyze the correlation between IL-10 -592G/A, -819T/C, and -1082A/C polymorphisms and risk of HCC, with results being expressed as odds ratios (ORs) and their $95 \%$ confidence intervals $(95 \% \mathrm{Cls})$. A P value less than 0.05 was considered to indicate a significant difference.

\section{RESULTS}

The characteristics of HBV-related HCC patients and control subjects are reported in Table 1. The average participant age in these groups was $56.32 \pm 7.55$ and $54.70 \pm 8.14$ years for patients and controls, respectively. No significant difference was found between patients and controls in terms of gender (chi-square $=0.86, P=0.35$ ), smoking (chi-square $=1.54, P=0.22$ ), or drinking habit (chi-square $=1.11, \mathrm{P}=0.29$ ). Compared with the control subjects, HCC patients were more likely to be older $(t=1.94, \mathrm{P}=0.03$ ), have a family history of cancer (chi-square = 17.86, $\mathrm{P}<0.001)$, and exhibit higher ALT $(t=13.32, \mathrm{P}<0.001)$ and AST $(t=12.63, \mathrm{P}<0.001)$ levels. Of the 173 patients with HBV-related HCC, 65 (37.57\%) were at TNM stage I-II, while 108 $(62.43 \%)$ were at stage III-IV. With respect to Child-Pugh classification, $42(24.28 \%)$ patients were categorized as class A, $70(40.46 \%)$ class B, and $61(35.26 \%)$ class C.

Genotype frequencies of IL-10 -592G/A, -819T/C, and -1082A/C polymorphisms are shown in Table 2. A goodness-of-fit chi-square test revealed the genotype distributions of these variants to conform to HWE. Using a chi-square test, we found that the distribution of $I L$ $10-592 \mathrm{G} / \mathrm{A}$ genotypes significantly differed between HBV-related HCC patients and control subjects (chi-square $=6.30, P=0.04$ ). However, no such difference was observed in regard to $-819 \mathrm{~T} / \mathrm{C}$ (chi-square $=1.37, \mathrm{P}=0.51$ ) and $-1082 \mathrm{~A} / \mathrm{C}$ (chi-square $=1.29, \mathrm{P}=0.53$ ) genotype distributions. 
Table 1. Comparison of demographic and clinical data relating to hepatitis B-related hepatocellular carcinoma patients and control subjects.

\begin{tabular}{|c|c|c|c|c|c|c|}
\hline Variable & Patients & $\%$ & Controls & $\%$ & Chi-square test & $P$ value \\
\hline Age (years) & & $56.32 \pm 7.55$ & & $54.70 \pm 8.14$ & 1.94 & 0.03 \\
\hline \multicolumn{7}{|l|}{ Gender } \\
\hline Female & 110 & 63.58 & 107 & 58.79 & & \\
\hline Male & 63 & 36.42 & 75 & 41.21 & 0.86 & 0.35 \\
\hline \multicolumn{7}{|l|}{ Smoking } \\
\hline No & 108 & 62.43 & 125 & 68.68 & & \\
\hline Yes & 65 & 37.57 & 57 & 31.32 & 1.54 & 0.22 \\
\hline \multicolumn{7}{|l|}{ Drinking } \\
\hline No & 95 & 54.91 & 110 & 60.44 & & \\
\hline Yes & 78 & 45.09 & 72 & 39.56 & 1.11 & 0.29 \\
\hline \multicolumn{7}{|c|}{ Family history of cancer } \\
\hline No & 136 & 78.61 & 171 & 93.96 & & \\
\hline Yes & 37 & 21.39 & 11 & 6.04 & 17.86 & $<0.001$ \\
\hline $\mathrm{ALT}($ mean $\pm \mathrm{SD})$ & \multicolumn{2}{|c|}{$55.85 \pm 27.43$} & \multicolumn{2}{|c|}{$27.43 \pm 8.54$} & 13.32 & $<0.001$ \\
\hline AST (mean \pm SD) & \multicolumn{2}{|c|}{$54.71 \pm 25.53$} & \multicolumn{2}{|c|}{$29.57 \pm 7.83$} & 12.63 & $<0.001$ \\
\hline \multicolumn{7}{|l|}{ TNM stage } \\
\hline$|-I|$ & 65 & 37.57 & & & & \\
\hline III-IV & 108 & 62.43 & & & & \\
\hline \multicolumn{7}{|c|}{ Child-Pugh classification } \\
\hline $\mathrm{A}$ & 42 & 24.28 & & & & \\
\hline $\mathrm{B}$ & 70 & 40.46 & & & & \\
\hline C & 61 & 35.26 & & & & \\
\hline
\end{tabular}

$\mathrm{ALT}=$ alanine aminotransferase; $\mathrm{AST}=$ aspartate aminotransferase; SD = standard deviation; TNM = tumor-nodemetastasis.

Table 2. Genotype distributions of $/ L-10-592 \mathrm{G} / \mathrm{A},-819 \mathrm{~T} / \mathrm{C}$, and $-1082 \mathrm{~A} / \mathrm{C}$ gene polymorphisms in hepatitis B-related hepatocellular carcinoma patient and control groups.

\begin{tabular}{|c|c|c|c|c|c|c|c|c|}
\hline \multirow[t]{2}{*}{ Genotype } & \multirow[t]{2}{*}{ Patients $(\mathrm{N}=173)$} & \multirow[t]{2}{*}{$\%$} & \multirow[t]{2}{*}{ Controls $(\mathrm{N}=182)$} & \multirow[t]{2}{*}{$\%$} & \multicolumn{2}{|c|}{ HWE P value } & \multirow[t]{2}{*}{ Chi-square } & \multirow[t]{2}{*}{$P$ value } \\
\hline & & & & & Patients & Controls & & \\
\hline \multicolumn{9}{|l|}{$-592 \mathrm{~A} / \mathrm{C}$} \\
\hline AA & 57 & 32.95 & 79 & 43.41 & & & & \\
\hline AG & 81 & 46.82 & 81 & 44.50 & & & & \\
\hline GG & 35 & 20.23 & 22 & 12.09 & 0.53 & 0.86 & 6.30 & 0.04 \\
\hline \multicolumn{9}{|l|}{$-819 \mathrm{~T} / \mathrm{C}$} \\
\hline TT & 74 & 42.77 & 86 & 47.25 & & & & \\
\hline TC & 77 & 44.51 & 78 & 42.86 & & & & \\
\hline $\mathrm{CC}$ & 22 & 12.72 & 17 & 9.34 & 0.78 & 0.91 & 1.37 & 0.51 \\
\hline \multicolumn{9}{|l|}{$-1082 A / G$} \\
\hline AA & 83 & 47.98 & 96 & 52.75 & & & & \\
\hline AC & 74 & 42.77 & 74 & 40.66 & & & & \\
\hline $\mathrm{CC}$ & 16 & 9.25 & 12 & 6.59 & 0.93 & 0.65 & 1.29 & 0.53 \\
\hline
\end{tabular}

HWE = Hardy-Weinberg equilibrium.

We further analyzed the correlation between the three $I L-10$ polymorphisms and susceptibility to HBV-related HCC using unconditional logistic regression analyses. We found that the $-592 \mathrm{G} / \mathrm{A} \mathrm{GG}$ genotype was associated with increased risk of $\mathrm{HCC}(\mathrm{OR}=2.20,95 \% \mathrm{Cl}=1.12$ 4.38) compared to the AA genotype (Table 3). Under a dominant model, the $A G+G G$ genotype correlated with susceptibility to HBV-related HCC compared to the AA genotype, with an OR $(95 \% \mathrm{Cl})$ of $1.56(1.02-2.48)$. In addition, the use of a recessive model revealed the GG genotype to be associated with elevated risk of $\mathrm{HCC}$ compared to the $\mathrm{AA}+\mathrm{AG}$ genotype $(\mathrm{OR}=1.85,95 \% \mathrm{Cl}$ $=1.01-3.47)$. However, we did not observe a significant association between $/ L-10-819 \mathrm{~T} / \mathrm{C}$ and $-1082 \mathrm{~A} / \mathrm{C}$ polymorphisms and development of HBV-related HCC under codominant, dominant, or recessive models. 


\begin{tabular}{|c|c|c|c|c|c|c|}
\hline Polymorphism & Patients $(\mathrm{N}=173)$ & $\%$ & Controls $(\mathrm{N}=182)$ & $\%$ & OR $(95 \% \mathrm{Cl})$ & $P$ value \\
\hline \multicolumn{7}{|l|}{$-592 A / C$} \\
\hline \multicolumn{7}{|l|}{ Codominant } \\
\hline $\mathrm{AA}$ & 57 & 32.95 & 79 & 43.41 & Reference & \\
\hline$A G$ & 81 & 46.82 & 81 & 44.5 & $1.39(0.85-2.25)$ & 0.16 \\
\hline GG & 35 & 20.23 & 22 & 12.09 & $2.20(1.12-4.38)$ & 0.01 \\
\hline \multicolumn{7}{|l|}{ Dominant } \\
\hline AA & 57 & 32.95 & 79 & 43.41 & Reference & \\
\hline$A G+G G$ & 116 & 67.05 & 103 & 56.59 & $1.56(1.02-2.48)$ & 0.04 \\
\hline \multicolumn{7}{|l|}{ Recessive } \\
\hline$A A+A G$ & 138 & 79.77 & 160 & 87.91 & Reference & \\
\hline GG & 35 & 20.23 & 22 & 12.09 & $1.85(1.01-3.47)$ & 0.03 \\
\hline \multicolumn{7}{|l|}{$-819 \mathrm{~T} / \mathrm{C}$} \\
\hline \multicolumn{7}{|l|}{ Codominant } \\
\hline TT & 74 & 42.77 & 86 & 47.25 & Reference & \\
\hline TC & 77 & 44.51 & 78 & 42.86 & $1.15(0.72-1.83)$ & 0.54 \\
\hline $\mathrm{CC}$ & 22 & 12.72 & 17 & 9.34 & $1.50(0.70-3.26)$ & 0.25 \\
\hline \multicolumn{7}{|l|}{ Dominant } \\
\hline TT & 74 & 42.77 & 86 & 47.25 & Reference & \\
\hline $\mathrm{TC}+\mathrm{CC}$ & 99 & 57.23 & 95 & 52.2 & $1.21(0.78-1.88)$ & 0.37 \\
\hline \multicolumn{7}{|l|}{ Recessive } \\
\hline $\mathrm{TT}+\mathrm{TC}$ & 151 & 87.28 & 164 & 90.11 & Reference & \\
\hline $\mathrm{CC}$ & 22 & 12.72 & 17 & 9.34 & $1.41(0.68-2.93)$ & 0.32 \\
\hline \multicolumn{7}{|l|}{$-1082 \mathrm{~A} / \mathrm{G}$} \\
\hline \multicolumn{7}{|l|}{ Codominant } \\
\hline $\mathrm{AA}$ & 83 & 47.98 & 96 & 52.75 & Reference & \\
\hline$A C$ & 74 & 42.77 & 74 & 40.66 & $1.16(0.73-1.83)$ & 0.51 \\
\hline $\mathrm{CC}$ & 16 & 9.25 & 12 & 6.59 & $1.54(0.64-3.79)$ & 0.29 \\
\hline \multicolumn{7}{|l|}{ Dominant } \\
\hline AA & 83 & 47.98 & 96 & 52.75 & Reference & \\
\hline$A C+C C$ & 90 & 52.02 & 86 & 47.25 & $1.21(0.78-1.88)$ & 0.37 \\
\hline \multicolumn{7}{|l|}{ Recessive } \\
\hline$A A+A C$ & 157 & 90.75 & 170 & 93.41 & Reference & \\
\hline $\mathrm{CC}$ & 16 & 9.25 & 12 & 6.59 & $1.44(0.62-3.45)$ & 0.35 \\
\hline
\end{tabular}

$\mathrm{OR}=$ odds ratio; $\mathrm{Cl}=$ confidence interval.

\section{DISCUSSION}

In this hospital-based case-control study, we investigated the role of three important polymorphisms in the IL-10 gene, $-592 \mathrm{G} / \mathrm{A},-819 \mathrm{~T} / \mathrm{C}$, and $-1082 \mathrm{~A} / \mathrm{C}$, in the risk of HBV-related HCC. We found the IL-10 -592G/A variant to be associated with increased risk of this disease. Moreover, this significant relationship persisted even after adjusting for confounding variables.

The candidate gene approach is increasingly being adopted to distinguish susceptibility genes that may trigger the initiation and progression of various types of cancer. One such gene possibly associated with HCC is IL-10. Previous studies have reported associations between polymorphisms of this gene and the development of cancers, as well as several other diseases, including acute pancreatitis, coronary artery disease, and colorectal, gastric, oral, lung, esophageal, and breast cancers (Miteva et al., 2014; Qi et al., 2014; Hsu et al., 2015; Jia et al., 2015; Kumar et al., 2015; Vinod et al., 2015; Xu and Liu, 2015; Yang and Fa, 2015; Zhang et al., 2015b). For instance, Miteva et al. (2014) reported that the IL-10 -1082A/G polymorphism has a significant impact on the development of colorectal cancer. Qi et al. (2014) conducted a meta-analysis of 12 studies, finding that the $-592 \mathrm{G} / \mathrm{A}$ variant correlates with increased risk of gastric cancer among Asians, while Hsu et al. (2015) reported that Taiwanese carriers of the -819T/C CT genotype have a 3.32-fold increased risk of oral cancer. Moreover, Zhang et al. (2015b) observed that the $I L$ - 
$10-592 \mathrm{G} / \mathrm{A}$ and -819T/C polymorphisms are closely connected to lung cancer susceptibility in a Chinese population. However, an investigation conducted in an Indian population found that only the -819T/C SNP appears to play a role in the development of gastric cancer (Kumar et al., 2015). Yang and $\mathrm{Fa}(2015)$ indicated that $I L-10-1082 A / G$ constitutes a candidate biomarker for the prediction of susceptibility to esophageal cancer, while Vinod et al. (2015) suggested that the AA genotype of this SNP correlates with breast cancer oncogenesis in the South Indian population.

Several previous studies have examined the association between $I L-10$ gene polymorphisms and development of HCC (Ben-Ari et al., 2003; Heneghan et al., 2003; Tseng et al., 2006; Truelove et al., 2008; Qiu et al., 2011; Wei et al., 2011). Tseng et al. (2006) demonstrated that the $-592 \mathrm{G} / \mathrm{A}$ variant affects HCC risk, while Qiu et al. (2011) reported that certain genotypes of the -819 and -592 SNPs increase and decrease susceptibility, respectively. Furthermore, Truelove et al. (2008) suggested that IL-10 gene sequence variations influence HBV infection outcome, although Ben-Ari et al. (2003) reported that the polymorphisms investigated in the current study are not associated with development of chronic HBV infection and related diseases. Finally, Heneghan et al. (2003) conducted a study among the Hong Kong Chinese population, finding that IL-10 polymorphisms do not contribute to HCC susceptibility. In our analysis, the IL-10 -592G/A polymorphism was seen to be associated with increased risk of HBV-related HCC, but no such relationship was established in regard to the $-819 \mathrm{~T} / \mathrm{C}$ and $-1082 \mathrm{~A} / \mathrm{C}$ variants.

We conclude that the $I L-10-592 \mathrm{G} / \mathrm{A}$ gene polymorphism does play a role in susceptibility to HBV-related HCC under codominant, dominant, and recessive models. Future studies using larger sample sizes and employing either similar or different analytic strategies may help to elucidate the impact of IL-10 gene polymorphisms on risk of HBV-related HCC.

\section{Conflicts of interest}

The authors declare no conflict of interest.

\section{ACKNOWLEDGMENTS}

Research supported by the National Natural Science Foundation of China (NSFC; \#81372440).

\section{REFERENCES}

Ben-Ari Z, Mor E, Papo O, Kfir B, et al. (2003). Cytokine gene polymorphisms in patients infected with hepatitis B virus. Am. J. Gastroenterol. 98: 144-150. http://dx.doi.org/10.1111/j.1572-0241.2003.07179.x

Ferlay J, Soerjomataram I, Ervik M, Dikshit R, et al. (2013). GLOBOCAN 2012 v1.0, Cancer Incidence and Mortality Worldwide: IARC CancerBase No. 11. International Agency for Research on Cancer, Lyon, France. Available [http://globocan.iarc.fr/ Pages/fact_sheets_cancer.aspx]. Accessed January 18, 2016.

Heneghan MA, Johnson PJ, Clare M, Ho S, et al. (2003). Frequency and nature of cytokine gene polymorphisms in hepatocellular carcinoma in Hong Kong Chinese. Int. J. Gastrointest. Cancer 34: 19-26. http://dx.doi.org/10.1385/IJGC:34:1:19

Holan V, Zajicova A, Javorkova E, Trosan P, et al. (2014). Distinct cytokines balance the development of regulatory T cells and interleukin-10-producing regulatory B cells. Immunology 141: 577-586. http://dx.doi.org/10.1111/imm.12219

Hsu HJ, Yang YH, Shieh TY, Chen CH, et al. (2015). TGF-b1 and IL-10 single nucleotide polymorphisms as risk factors for oral cancer in Taiwanese. Kaohsiung J. Med. Sci. 31: 123-129. http://dx.doi.org/10.1016/j.kjms.2014.12.003

Jia HL, Sun PL and Lu CQ (2015). Investigation of the association between Interleukin-10 polymorphisms and risk of acute pancreatitis in a Chinese population. Genet. Mol. Res. 14: 15876-15881. http://dx.doi.org/10.4238/2015.December.1.39

Kim J, Cho YA, Choi IJ, Lee YS, et al. (2012). Effects of interleukin-10 polymorphisms, Helicobacter pylori infection, and smoking on the risk of noncardia gastric cancer. PLoS One 7: e29643. http://dx.doi.org/10.1371/journal.pone.0029643 
Kumar S, Kumari N, Mittal RD, Mohindra S, et al. (2015). Association between pro-(IL-8) and anti-inflammatory (IL-10) cytokine variants and their serum levels and $H$. pylori-related gastric carcinogenesis in northern India. Meta Gene 6: 9-16. http:// dx.doi.org/10.1016/j.mgene.2015.07.008

Labib HA, Ahmed HS, Shalaby SM, Wahab EA, et al. (2015). Genetic polymorphism of IL-23R influences susceptibility to HCVrelated hepatocellular carcinoma. Cell. Immunol. 294: 21-24. http://dx.doi.org/10.1016/j.cellimm.2015.01.012

Liu F, Luo LM, Wei YG, Li B, et al. (2015). Polymorphisms of the CYP1B1 gene and hepatocellular carcinoma risk in a Chinese population. Gene 564: 14-20. http://dx.doi.org/10.1016/j.gene.2015.03.035

Ma WL, Lai HC, Yeh S, Cai X, et al. (2014). Androgen receptor roles in hepatocellular carcinoma, fatty liver, cirrhosis and hepatitis. Endocr. Relat. Cancer 21: R165-R182. http://dx.doi.org/10.1530/ERC-13-0283

Miteva LD, Stanilov NS, Deliysky TS and Stanilova SA (2014). Significance of -1082A/G polymorphism of IL10 gene for progression of colorectal cancer and IL-10 expression. Tumour Biol. 35: 12655-12664. http://dx.doi.org/10.1007/s13277-014-2589-2

Qi M, Liu DM, Pan LL and Lin YX (2014). Interleukin-10 gene -592C>A polymorphism and susceptibility to gastric cancer. Genet. Mol. Res. 13: 8954-8961. http://dx.doi.org/10.4238/2014.October.31.10

Qiu XQ, Bei CH, Yu HP, Zeng XY, et al. (2011). [Study on the relationship between single-nucleotide polymorphisms in IL-6, IL-10 genes and HBV-related hepatocellular carcinoma]. Zhonghua Liu Xing Bing Xue Za Zhi 32: 510-513.

Rad R, Dossumbekova A, Neu B, Lang R, et al. (2004). Cytokine gene polymorphisms influence mucosal cytokine expression, gastric inflammation, and host specific colonisation during Helicobacter pylori infection. Gut 53: 1082-1089. http://dx.doi. org/10.1136/gut.2003.029736

Sheu MJ, Hsieh MJ, Chiang WL, Yang SF, et al. (2015). Fibroblast growth factor receptor 4 polymorphism is associated with liver cirrhosis in hepatocarcinoma. PLoS One 10: e0122961. http://dx.doi.org/10.1371/journal.pone.0122961

Szkaradkiewicz A, Karpiński TM, Drews M, Borejsza-Wysocki M, et al. (2010). Natural killer cell cytotoxicity and immunosuppressive cytokines (IL-10, TGF-beta1) in patients with gastric cancer. J. Biomed. Biotechnol. $2010: 901564$. http://dx.doi.org/10.1155/2010/901564

Tanikawa T, Wilke CM, Kryczek I, Chen GY, et al. (2012). Interleukin-10 ablation promotes tumor development, growth, and metastasis. Cancer Res. 72: 420-429. http://dx.doi.org/10.1158/0008-5472.CAN-10-4627

Truelove AL, Oleksyk TK, Shrestha S, Thio CL, et al. (2008). Evaluation of IL10, IL19 and IL20 gene polymorphisms and chronic hepatitis B infection outcome. Int. J. Immunogenet. 35: 255-264. http://dx.doi.org/10.1111/j.1744-313X.2008.00770.x

Tseng LH, Lin MT, Shau WY, Lin WC, et al. (2006). Correlation of interleukin-10 gene haplotype with hepatocellular carcinoma in Taiwan. Tissue Antigens 67: 127-133. http://dx.doi.org/10.1111/j.1399-0039.2006.00536.x

Vinod C, Jyothy A, Vijay Kumar M, Raman RR, et al. (2015). A common SNP of IL-10 (-1082A/G) is associated with increased risk of premenopausal breast cancer in South Indian women. Iran. J. Cancer Prev. 8: e3434. http://dx.doi.org/10.17795/ijcp-3434

Wang J, Ni H, Chen L and Song WQ (2006). Interleukin-10 promoter polymorphisms in patients with hepatitis B virus infection or hepatocellular carcinoma in Chinese Han ethnic population. HBPD INT 5: 60-64.

Wei YG, Liu F, Li B, Chen X, et al. (2011). Interleukin-10 gene polymorphisms and hepatocellular carcinoma susceptibility: a meta-analysis. World J. Gastroenterol. 17: 3941-3947. http://dx.doi.org/10.3748/wjg.v17.i34.3941

$\mathrm{Xu} \mathrm{HM}$ and Liu YR (2015). Role of interleukin-10 gene polymorphisms in the development of coronary artery disease in Chinese population. Genet. Mol. Res. 14: 15869-15875. http://dx.doi.org/10.4238/2015.December.1.38

Yang HI, Yeh SH, Chen PJ, lloeje UH, et al.; REVEAL-HBV Study Group (2008). Associations between hepatitis B virus genotype and mutants and the risk of hepatocellular carcinoma. J. Natl. Cancer Inst. 100: 1134-1143. http://dx.doi. org/10.1093/jnci/djn243

Yang $\mathrm{Y}$ and $\mathrm{Fa} X$ (2015). Role of IL-10 gene polymorphisms on the susceptibility for esophageal cancer and its association with environmental factors. Int. J. Clin. Exp. Pathol. 8: 9580-9585.

Yu Z, Liu Q, Huang C, Wu M, et al. (2013). The interleukin $10-819 \mathrm{C} / \mathrm{T}$ polymorphism and cancer risk: a HuGE review and metaanalysis of 73 studies including 15,942 cases and 22,336 controls. OMICS 17: 200-214. http://dx.doi.org/10.1089/omi.2012.0089

Zhang H, Li G and Zhang Z (2015a). Association between MTHFR A1298C polymorphism and hepatocellular carcinoma risk. Int. J. Clin. Exp. Med. 8: 9135-9141.

Zhang YM, Mao YM and Sun YX (2015b). Genetic polymorphisms of IL-6 and IL-10 genes correlate with lung cancer in neversmoking Han population in China. Int. J. Clin. Exp. Med. 8: 1051-1058.

Zhao JH, Li H and Di J (2014). [Relation of polymorphisms of the XPD and GSTM1 genes with susceptibility to hepatocellular carcinoma in Qinghai Tibetans]. Zhonghua Gan Zang Bing Za Zhi 22: 831-836.

Zhao H, Zou LW, Zheng SS and Geng XP (2015). Association between the NQO1 C609T polymorphism with hepatocellular carcinoma risk in the Chinese population. Asian Pac. J. Cancer Prev. 16: 1821-1825. http://dx.doi.org/10.7314/ APJCP.2015.16.5.1821

Zheng X, Han C, Shan R, Zhang H, et al. (2015). Association of interleukin-6 polymorphisms with susceptibility to hepatocellular carcinoma. Int. J. Clin. Exp. Med. 8: 6252-6256. 